\title{
THE ECONOMIC CRISIS AND COMPANY MANAGEMENT: INFLUENCES AND CONSEQUENCES
}

\author{
Barbora Antonová, Šárka Zapletalová
}

\section{Introduction}

The global crisis in 2007-2012 brought about dramatic changes to the business environment in both the global and international context. The impact of this crisis is visible in the changed market supply and demand as well as in the management of businesses across all industries.

An industry particularly hit was tourism, due to its nature, as it deals with "dispensable" products. These are products not necessarily needed by the customer, ones that only help to improve the life quality and living standard. Businesses in the tourism sector affected by the world crisis are looking for new possibilities and opportunities in the market. On one hand, the global crisis brought about considerable challenge to survival of companies in the tourism, on the other hand, it provided a whole range of potential. Businesses need to find and build a sustainable competitive advantage in the long term so that they can survive and continue to expand their service portfolio. The new terms and the changing environment have urged to formulate new strategies and new strategic targets so that they match the market requirements, being sufficiently competitive at the same time.

The aim of the present article is to illustrate the impact of the economic crisis on the crisis management in selected businesses within the tourism industry, specifically accommodation providers. The initial section of the paper will discuss a theoretical context of the relation between the economic crisis and management of the tourism business. This theoretical background will then lead to establishing hypotheses regarding the determination of the impact of the global economic crisis on company management. The subsequent section will present the methodology used, the data and results from the primary research. The data presented in this paper were obtained through the primary research among providers of accommodation services in the Czech Republic.

\section{The Economic Crisis and lts Impact on Tourism in the Czech Republic}

The global business environment is characterized by high volatility and turbulent developments. So far, the most significant event of the 21 st century effecting, shaping and dramatically recasting the global business environment has been the global crisis (sometimes referred to as the global financial crisis) in 2007-2012. The roots of the current economic crisis, along with parallel developments, can be found in the previous wave of recessions in the 1990s, starting with the East Asian crisis, Brazilian, Russian, up to the dotcom bubble (the crisis triggered in the 1990s by a flow of investments into the IT). Today, there is already a range of studies investigating the causes of the current crisis, or setting it within a historic and global context [11].

This crisis has been labelled by a number of economists as the worst financial crisis since the great depression in the 1930s [13]. The main impetus behind the rise of the global financial crisis was the mortgage crisis in the United States, which began to manifest itself since mid-March 2007, with a significant impact on the US capital markets since mid-July 2007. The roots of the crisis lie in the American mortgage market through provisions of cheap mortgages. 
What at first seemed to be a mere crisis of the financial market, extended with time across the whole economy in the USA. The decline in consumption of American households as one of the manifestations of the crisis was reflected in a declining demand for domestic and foreign products. This decrease in demand for foreign products extended the crisis to other countries where it slowed down the economic growth. Because of the high degree of global interconnection all over the world as well as liberalisation of international trade, the crisis affected also the countries which were not directly affected by the financial crisis. The crisis spilled over to Europe in the first half of August 2007, and after Europe, China and Russia were next being affected. The nervousness that has affected the markets since the last wave of decline in orders resulted in a recession affecting major economies worldwide, thus turning the initial financial crisis into the global economic crisis [18].

In the OECD countries, the first problems in financial markets began to occur by slowing down the economic growth at the turn 2007 and 2008. The recession began around mid-2008 and as early as the second half and towards the 2009, it reached the bottom. The decline in real economies were markedly visible in unemployment, which gradually went up to $10 \%$ both in the USA and the EU, and despite the improvement outlook in GDP, it remains a major problem. As a result of attempts to address the financial crisis, the overall debt ratio of nations soared, reflected in new turbulences in financial markets and in restrictive fiscal policies.

The primary indicator of the crisis within the Czech Republic was the slumping Czech currency, the crown, which generated problems particularly for companies involved in imports and exports to and from the country. The heaviest initial blow of the economic crisis was received by manufacturing industries [8]. The crisis then continued spreading, and its influence, the positive one as well as, more often, the negative one, was noticed in nearly all business sectors.

Despite the original assumptions tended to claim that "things would be better out in 2010", as we may see in the subsequent quotation of the 2009 statement, the overall condition of the Czech economy failed to improve. "Business people are concerned that the economic recession has not reached its assumed bottom yet. Companies continue to struggle with a considerable decline in orders, and the fact that most companies expect a reversal for the better as late as in 2010 bodes badly for the national economy", said the President of the Economic Chamber, Petr Kužel [16].

The crisis impact has been largely demonstrated by a mass job termination in manufacturing industries, stricter terms for mortgages and funding for real estate developer projects, reduced exports and consumer spending. Czech banks are more careful now when providing credits.

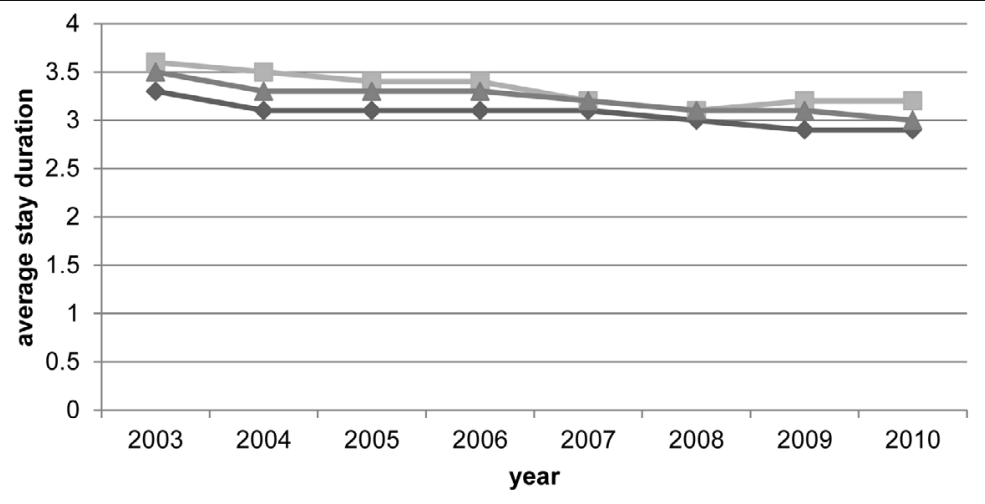

$\neg$ foreign visitors $\rightarrow$ domestic visitors $\rightarrow$ average duration 


\section{Ekonomie}

The economic crisis hit also the tourism industry, where it occurred later, but as a dramatic phenomenon, in particular for accommodation service providers, owners of travel agencies and similar. As early as 2007, the trend to reduce the average stay duration was noted. Visitors spent average 3.0 nights in lodging facilities (Figure 1).

The first effects of the global crisis were noted in 2008. Roughly in the second half of 2008, news started occurring in the Czech media covering the impact of the crisis on tourism, in particular in terms of declining demand for services. That is when the press started publishing news of a decline in the Czechs' interest in tours and a decreasing number of visitors to the Czech Republic.

Towards the end of 2009, the following prediction was offered by Mag Consulting director, Jaromír Beránek: "The crisis in the tourism industry, with its first symptoms recorded by statistical evidence as early as the second quarter of 2008 , will continue at least till the end of 2010 . The small and medium-sized

Fig. 2: Number of foreign and domestic visitors to public lodging facilities in the Czech Republic in 2003-2010

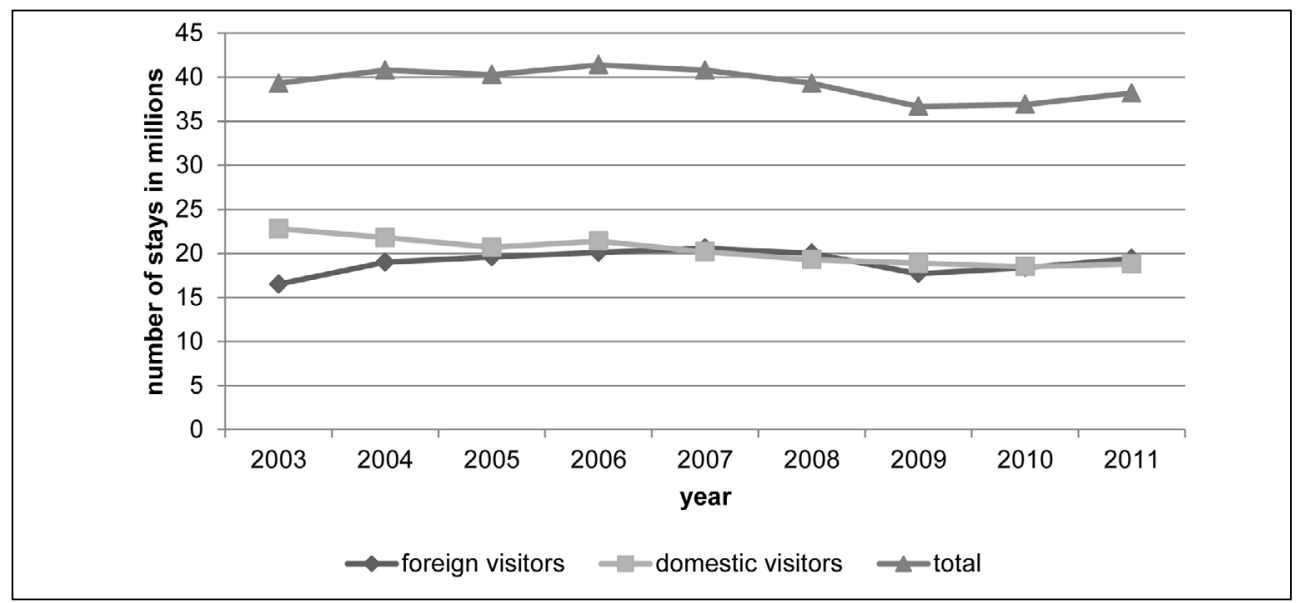

Number of foreign and domestic visitors to public lodging facilities in the Czech Republic in 2003-2010

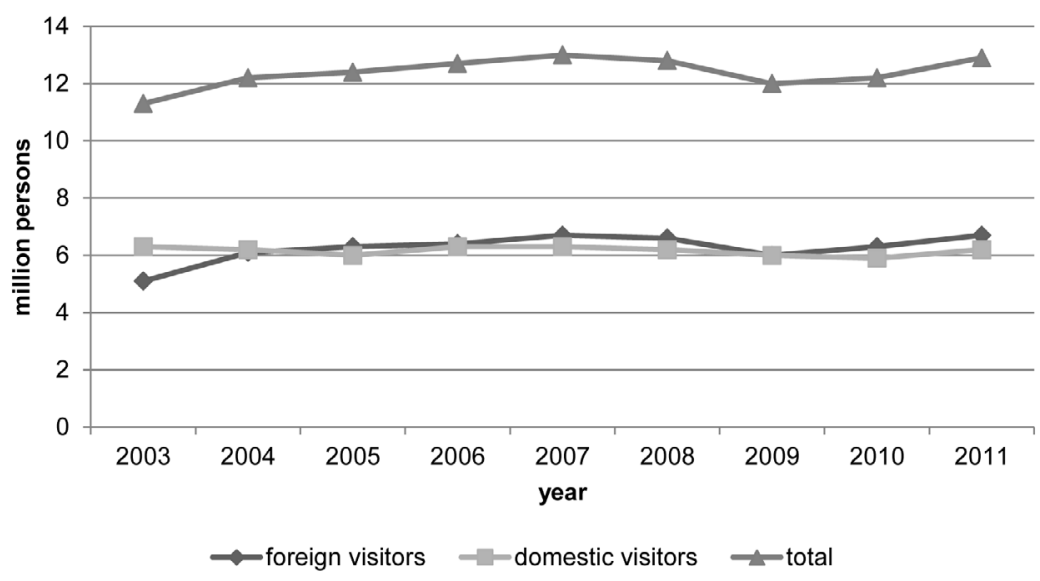


hotels can be assumed not to resist this kind of pressure, having to close down." [9]. In this case he was right.

A decrease both in visitor numbers and the stay of duration in public lodging facilities were noted (Figure 2, Figure 3).

As predicted by him, the number of accommodation providers in the Czech Republic really dwindled. Since the end of 2007 they began to wane in our country. As evidenced by the CSO statistics (Table 1), the most perceivable decline occurred between 2009 and 2010 , reaching over $4 \%$. The year 2010 was, of course, the year when the decrease in tourist traffic to the Czech Republic finally stopped. And Czech entrepreneurs in the tourism sector felt a change in the course of the year 2010 when in the summer foreign tourists started returning to the Czech Republic.

\begin{tabular}{|c|c|}
\hline Tab. 1: & $\begin{array}{l}\text { Number of accommodation } \\
\text { facilities in the Czech Republic }\end{array}$ \\
\hline & Number of group lodging facilities \\
\hline 2007 & 7,845 \\
\hline 2008 & 7,705 \\
\hline 2009 & 7,557 \\
\hline 2010 & 7,235 \\
\hline 2011 & 7,657 \\
\hline
\end{tabular}

A decline in visitor numbers and stay duration was noted again in 2009. The reduced numbers of visitors, overnight stays and stay duration were necessarily reflected in the tourism consumption, which is noted in the satellite balance of tourism. Tourism consumption is understood as the total volume of funds spent on tourism by non-residents and residents. The reduced consumption in tourism is matched with the decreased spending per trip (Figure 4, Figure 5).

The crisis in tourism, however, resulted not only in a decrease in potential clients, but it is also followed by a need to reduce costs. In many cases, this meant job redundancy. As said by Jaromír Beránek: "The number of people in the tourism in 2009 didn't change significantly, but the employers' revenues fell sharply. So they will have to cut on jobs, otherwise their existence would be challenged." According to a survey by the World Travel \& Tourism Council, in 2010 , there was a $2009 \%$ decrease in jobs in tourism, compared to 7 [4].

But as early as in 2010 , the first time since 2008 , the decline in visitor numbers and stay duration stopped. A growing trend in these fields was recorded also in 2011.

\section{Fig. 4: Consumption in incoming, outgoing and domestic tourism in the Czech Republic in 2003-2010}

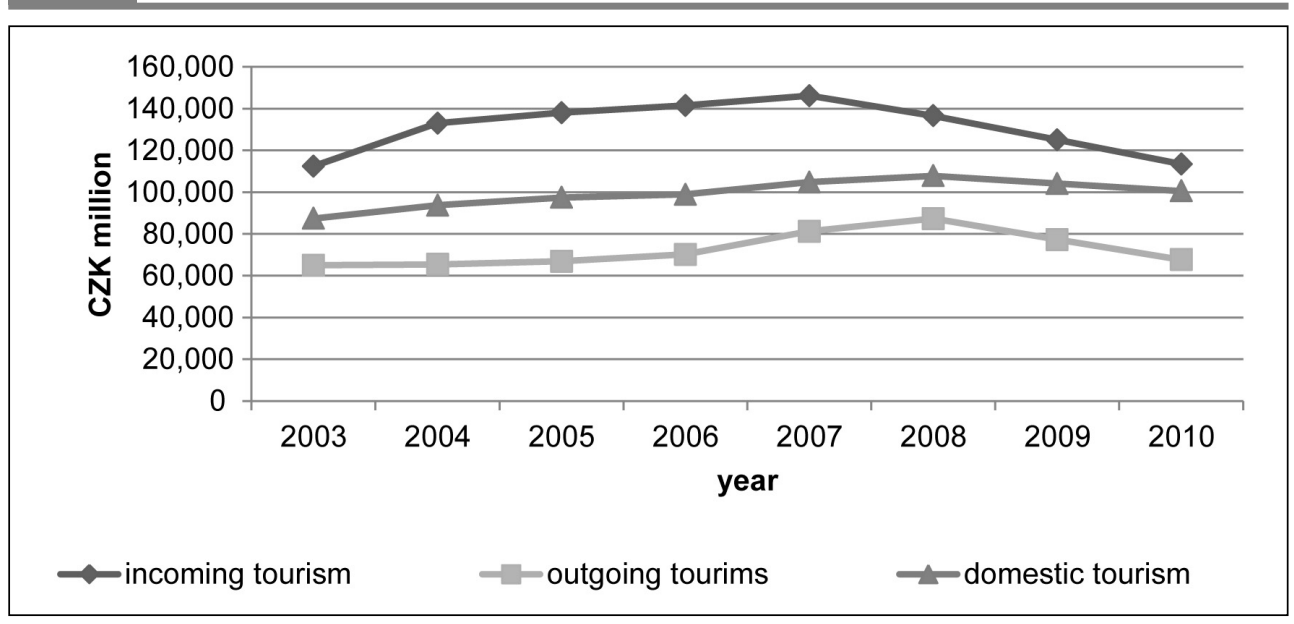


Fig. 5: Average spending by Czech residents per trip, in CZK

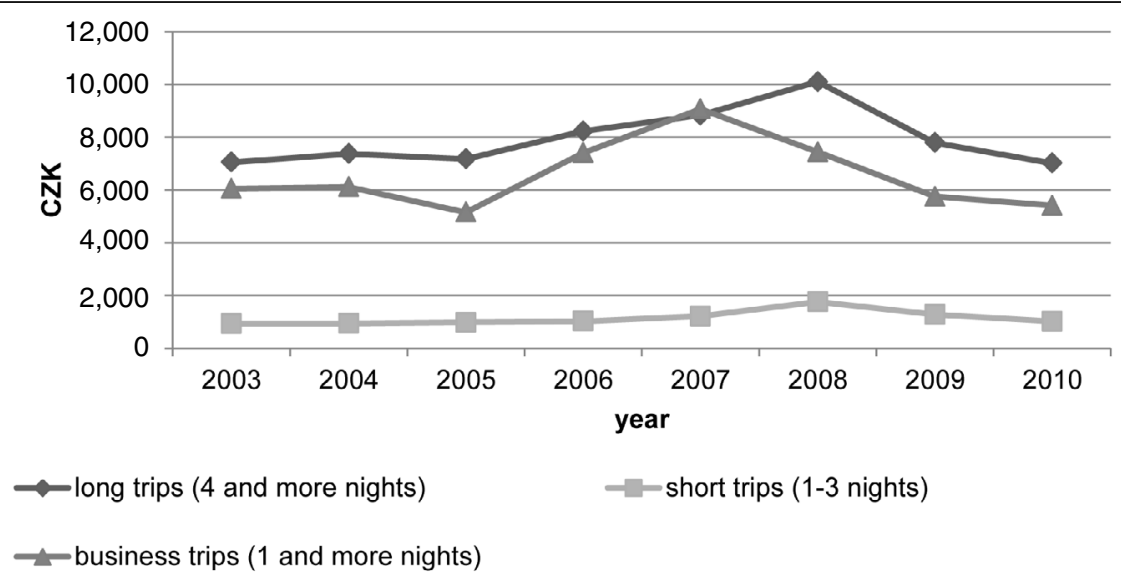

Source: [3]

\section{The Economic Crisis and Its Implications for Business Management in the Tourism Industry}

Quite naturally, at a time of a global crisis, there are changes in management of business within the industry, that is, tourism. By reducing available potential of clients, a visitor rate decreases in lodging facilities, with all accommodation providers, which means businesses often have to change management objectives. These changes are reflected in all levels of management, strategic, tactical and operational. In the tactical and operational context, companies address the operational issues related to the insufficient interest in services on offer by guests. On the strategic level, managers address the achievement of the objectives set down within the context of the market and corporate resources, and these changes result in a significant impact on the entire business.

The changes brought about by the global crisis, influencing the strategic management of accommodation providers, do not necessarily involve negative aspects, but they may also generate certain opportunities and impulses. The changing market conditions provide opportunities for private tourism businesses (and often a necessity) to generate new, competitive strategies for the domestic and international markets. The strategy of the accommodation provider is a result of a comprehensive managerial decision making process, formulating corporate objectives and steps towards achieving these, and is a result of a strategic management implemented by top managers. The success of the strategy depends on its degree of conformity with the new environment, the new market. It is the global crisis that is dramatically changing the business environment for accommodation providers. Companies active in tourism start developing new products for their future clients, such as tourism enhanced with food, wine trails, etc. These new strategies must both reflect the expectations on part of the customers and take the competition and their strategies into consideration. The success of the accommodation provider depends on the success of meeting customer requirements and generating a suitable competitive advantage. Building a sustainable competitive advantage is actually the objective of strategic management and the competitive advantage for today's clients of accommodation services within the framework of tourism is no longer a low price, but the service quality provided cost efficiently, as well as longterm customer handling. This strategy of the accommodation provider leads to generating long-term good relations with clients so that they keep coming back and using the services on offer again. It goes without saying that over 
the course of time, the competitive advantage will be eliminated to a certain extent, but the company needs to boost the competitive advantage on an ongoing basis, or search for and generate new competitive advantages. Creating and building a long-term competitive advantage is highly challenging due to the fierce competition in tourism. Sometimes it seems as if everything has been created and one cannot come up with something new, interesting and unique. Client handling may sometimes facilitate the process of generating a competitive advantage, as the client may becoming a certain provider of ideas.

The impact of every crisis is adverse for both the subject directly affected by the crisis as well as its environment. Thus, companies affected by the crisis try to eliminate their consequences, resorting to crisis management.

As with the classical management there are a number of definitions for crisis management. According to Antušák [1], crisis management is an interdisciplinary branch of science which can be understood as a coherent set of approaches, methods and recommendations applicable to a hierarchy-based, function-linked system of public authorities, legal entities and natural persons.

The word crisis is derived from Greek "krino" (meaning "separate, choose, decide, assess"), denoting a final, irrevocable decision made within two options, or an urgent need, a feeling of uncertainty, search for help and accident prevention [14]. As early as the 19th century, the notion of "crisis" was defined as uncertainty, suffering and test, referring to unknown future [12]. A crisis is a challenging, dramatic situation, a difficulty, mess, a period of certain instability or status of a change approaching. It is a significant, often unexpected event with a high potential of negative impact, a situation in which balance is significantly harmed. It is a negative deviation from the normal state.

As in many other fields, also in crisis management, the basic issue is to come up with a uniform definition for the notion of "crisis". The problem of inconsistent terminology and the definition of the basic concepts is typical of crisis management, especially in companies. Thus, it is necessary to focus on defining the principle that determines the outbreak of a crisis.
To define a company crisis, we will then invoke the definition by Zuzák and Königová [19]: "The crisis is understood as a situation of different duration when the decision is being made whether the company will, as a minimum, return to the status just before the occurrence of the crisis, or there is a potential threat to achieving company goals, and its possible further existence".

Crisis management is built on two pillars, these being a crisis management plan and crisis communication. Crisis management is in no way a set of mechanical rules, procedures and activities, but a set of innovative processes and progressive steps aimed at anticipating the comprehensive nature of the crisis [15].

The aim of crisis management in the tourism is to minimize the chances of the crisis outbreak, to reduce the damage scope, to minimize the crisis duration, to eliminate the consequences of negative factors of crisis situations and an effort to recover the system and return to its original state.

Based on the assumptions specified above, the following hypotheses were established.

Hypothesis 1a: A change in company management of the accommodation provider, as a result of the economic crisis, is manifested through a change in services on offer. There is a reduction in the supply of services.

Hypothesis 1b: A change in company management of the accommodation provider, as a result of the economic crisis, is manifested through a change in pricing for services on offer. Specifically, there is an increase in prices for services on offer.

Hypothesis 1c: A change in company management of the accommodation provider, as a result of the economic crisis, is manifested through a change in the staff size. The staff size is reduced.

Hypothesis 1d: A change in company management of the accommodation provider, as a result of the economic crisis, is influenced by the size of the company. Changes in the management practices are best visible in small and medium-sized enterprises.

Hypothesis 1e: A change in company management of the accommodation provider, as a result of the economic crisis, is influenced by the type of the company. A change in management occurs mostly in companies such 
as boarding houses, camp-sites, bungalow sites and hostels. Hotels as a category are not influenced considerably by changes in management.

Hypothesis 1f: A change in company management of the accommodation provider, as a result of the economic crisis, is influenced by the perception of the crisis and its impact on the company. A change in the company management occurs especially if the crisis is seen as a negative factor of the company development.

Hypothesis 2a: Perceptions of the economic crisis, as a major external factor of the accommodation provider, depend on the company size. Small and medium-sized enterprises perceive the economic crisis as a threat to their commercial activities.

Hypothesis 2b: Perceptions of the economic crisis, as a major external factor of the accommodation provider, depend on the company type. Boarding houses, camp-sites, bungalow sites and hostels perceive the economic crisis as a threat to their commercial activities.

Hypothesis 3a: The generation and use of a contingency plan is influenced by the size of the accommodation provider. Contingency plans tend to be made rather by large companies.

Hypothesis $3 \mathbf{b}$ : The generation and use of a contingency plan is influenced by the type of the accommodation provider. Contingency plans tend to be made by hotels.

\section{Research Study}

The aim of the research study was to determine the impact of the economic crisis on management of companies in the tourism industry, more specifically, in accommodation services. Because of the aim defined, the choice was made in favour of short-term research of primary data of descriptive and explanatory nature. As a research method, polling was selected, more specifically, spoken interviews. The research tool consisted in a questionnaire.

\subsection{Methodology}

To test the hypotheses established, a sample of accommodation providers operating in the Olomouc region was selected. The selection of informants for the research was made as an intentional quota selection.

The questionnaire was submitted to the managers or directors of 72 accommodation providers. In spite of the figure not being high, it is deemed statistically sufficient due to the explanatory nature of the research study. There were 72 applicable questionnaires. So the questionnaire return rate was $100 \%$. This high return rate for questionnaires was ensured by a polling officer present during the questionnaire filling process. Before presenting finally, the questionnaire was tested on the sample of 5 companies. The research was carried out in the Olomouc region in June-July 2012.

\section{Variables}

\section{Dependent variable}

The dependent variable in this study is a change in company management in tourism in 2007-2011.

\section{Independent variables}

Independent variables include crisis perceptions, changes in the scope of services on offer, modified pricing, changes in the staff size, the company type and the company size.

Crisis perception is about the company perceiving the crisis to be a positive or strictly negative factor for the company.

Changes in the service scope on offer (hereinafter referred to as services) denote if companies reduced, increased, or kept the scope of services.

Changes in pricing (prices) are about whether any changes were noted in the reference companies in 2007-2011.

Changes in the staff size (staff) denote if the reference companies increased the staff size or the staff size was left unchanged.

The company type (type) followed the systematic pattern used by the Czech Statistical Office, with these categories: 4-star hotels, 3 star hotels, 2 star hotels, 1 star hotels, other hotels, boarding houses, camp-sites, bungalow sites, hostels and others.

The company size (size) was indicated in the number of employees. This legislation distinguishes between four categories of business entities, these being micro-enterprises (1-10 employees), small business (up to 50 employees), mediumsized enterprises (50-250 employees), and large enterprises (more than 250 employees).

To analyse the data obtained, the software application SPSS 11.5 for Windows was employed. To test the hypotheses, an analysis of categorical data was used. To describe and 
analyse the relationship type of the qualitative variables (also known as categorical variables), an analysis of contingency tables was used, thus, we have an analysis of categorical data at hand. This is an analogy to the correlation analysis of continuous variables. The difference is that in case of analysing the frequency tables, both categorical variables are considered random [7]. The contingency tables are twodimensional tables produced by sorting based on two variables: the tables allow following marginal sums of lines and columns. Line/ /column lines can be expressed in absolute and relative frequencies [7]. Hypotheses for the contingency tables are usually defined in terms of stochastic independence, applying certain conditions. The relevant statistical tests are called sometimes good fit tests, comparing the compliance of variable metric diameters [7].

To measure the strength of the relationship in a contingency table, we suggest a number of coefficients working similarly as the correlation coefficient. The contingency table relies on an adjusted contingency coefficient according to Pearson and Cramer [7]. The Cramer coefficient may read: 0-0.1 (negligible dependence), 0.1-0.3 (weak dependence), 0.3-0.7 (high dependency), 0.7-1.0 (strong dependence) [2]. Hypothesis tests concerning the independence of categorical data are performed using the test statistics $\lambda 2$ (Pearson statistics - Pearson Chisquare). The test is based on a comparison of the frequency found (njk) and theoretical frequency $(n j . n k / n)$ of variant pairs which should be very similar in a relevant zero hypothesis. The Cramer coefficient and Pearson correlation coefficient involve values within the scope of 0 to 1 . A zero value in the table indicates no relation; the coefficients amounting to 1 indicate a complete relationship [7].

\subsection{Research Results}

Before proceeding with the analysis of categorical data and the deviance analysis, the diagnostics was performed for collinearity through correlation (table 2).

Tab. 2: Descriptive statistics and correlation analysis

\begin{tabular}{l|c|c|c|c|c|c|c|c|c|c} 
& SH & SO & $\mathbf{1}$ & $\mathbf{2}$ & $\mathbf{3}$ & $\mathbf{4}$ & $\mathbf{5}$ & $\mathbf{6}$ & $\mathbf{7}$ & $\mathbf{8}$ \\
\hline management & 1.61 & 0.491 & 1 & & & & & & & \\
\hline crisis perceptions & 4.38 & 3.265 & $-0.373^{* *}$ & 1 & & & & & & \\
\hline services & 2.38 & 0.615 & $0.256^{*}$ & $-0.232^{*}$ & 1 & & & & & \\
\hline prices & 2.06 & 0.948 & 0.229 & 0.020 & -0.181 & 1 & & & & \\
\hline staff & 2.50 & 0.805 & $0.250^{\star}$ & -0.190 & $0.242^{*}$ & -0.092 & 1 & & & \\
\hline type & 6.39 & 2.958 & 0.212 & $-0.234^{*}$ & $0.406^{* *}$ & 0.163 & $0.373^{* *}$ & 1 & & \\
\hline size & 1.17 & 0.411 & $-0.233^{*}$ & 0.173 & -0.139 & -0.133 & $-0.298^{*}$ & $-0.529^{* *}$ & 1 & \\
\hline contingency plan & 2.47 & 0.530 & -0.150 & 0.116 & $-0.248^{\star}$ & 0.003 & 0.033 & $-0.316^{* *}$ & $0.474^{* *}$ & 1 \\
\hline
\end{tabular}

* The correlation is significant at the $5 \%$ significance level.

* The correlation is significant at the $1 \%$ significance level.

$\mathrm{SH}$ - the mean, $\mathrm{SO}$ - relevant deviation

\section{Changes in Company Management due to Economic Crisis}

The research study allowed finding out that the economic crisis did not bring a change in management for most companies (refer to Figure 6).

Changes in company management, as a result of the economic crisis, were not influenced by the company size. The influence of the economic crisis failed to change pricing and reduced the staff size. The only change confirmed in business management, caused by the economic crisis, was a change in the service scope on offer. It was interesting to note that the offer scope grew, rather than declined (refer to Figure 7), which would have been expected.

To confirm the set of hypotheses $\mathrm{H} 1 \mathrm{a}-\mathrm{H} 1 \mathrm{e}$, an analysis of categorical data analysis was performed, with its results recorded in Table 3 below. 


\section{Ekonomie}

Fig. 6: Impact of the economic crisis on changes in management of service providers

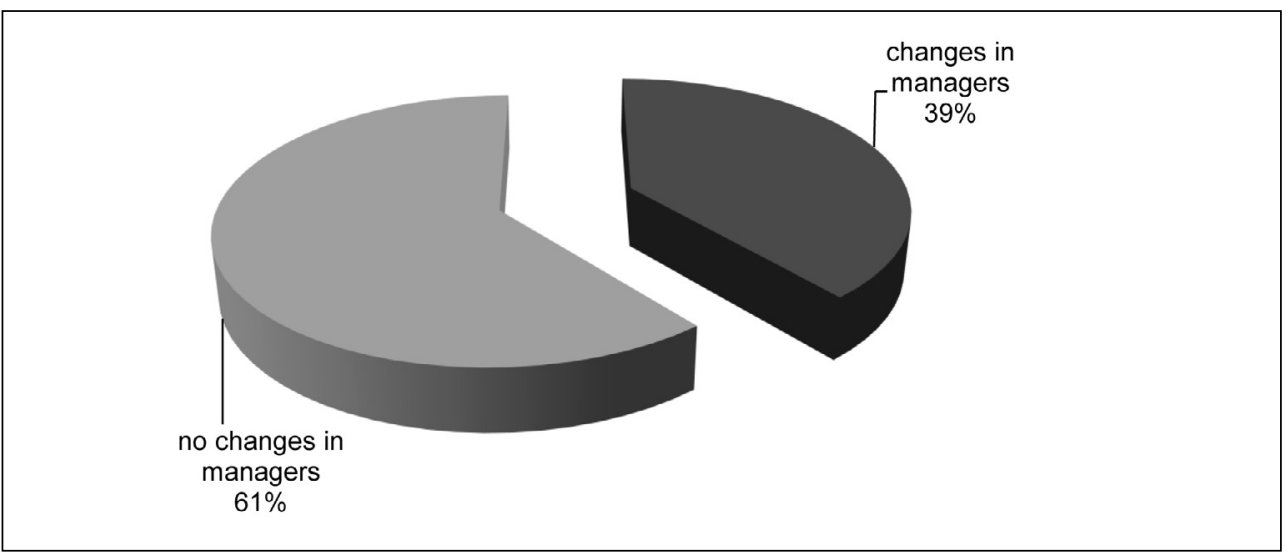

Source: custom data

Fig. 7: Changes in service scope due to changes in company management

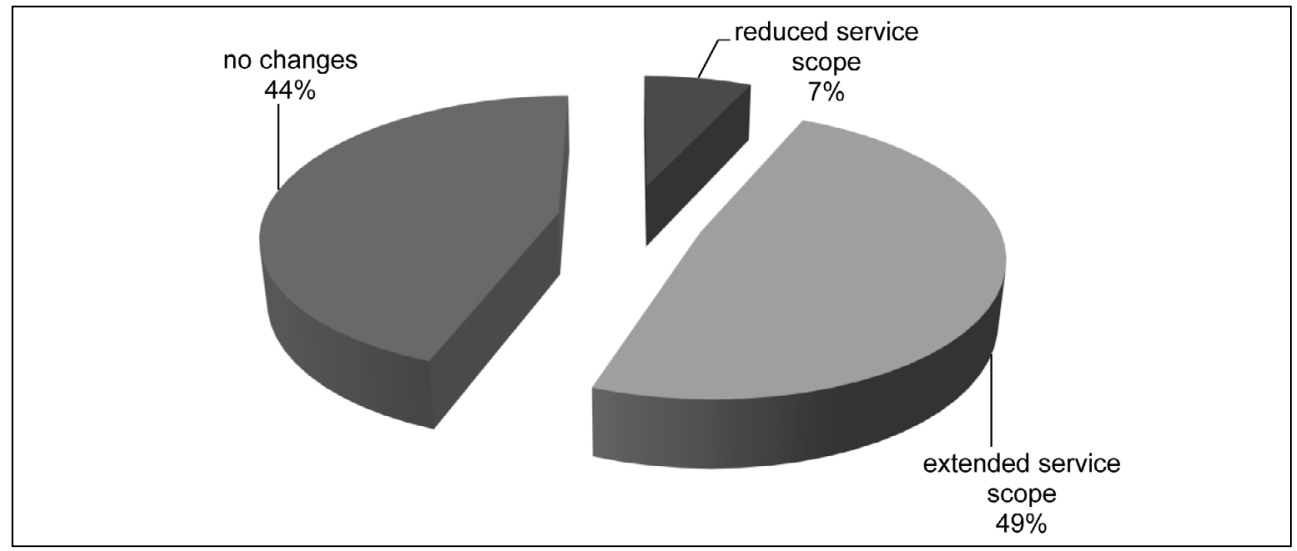

Source: custom data

\section{Tab. 3: Analysis results of categorical data for Hypotheses H1a-H1f}

\begin{tabular}{l|c|c|c} 
& Pearson coefficient & Cramer coefficient V & p \\
\hline change in service offer & 7.392 & 0.320 & 0.025 \\
\hline change in pricing & 4.180 & 0.241 & 0.124 \\
\hline change in staff size & 5.502 & 0.276 & 0.064 \\
\hline company size & 3.958 & 0.234 & 0.138 \\
\hline company type & 10.172 & 0.376 & 0.337 \\
\hline crisis perceptions & 14.047 & 0.442 & 0.015 \\
\hline
\end{tabular}

Source: custom data 
Hypothesis 1a presumed an influence of change in company management on service offer. This hypothesis was partly confirmed $(p<0.05)$. This means that the economic crisis has a certain impact on changing the service scope on offer, but the scope was not reduced (as assumed), but extended. The impact of this factor on the method choice indicates medium dependence $(\mathrm{V}=0.320)$. Hypothesis $1 \mathrm{~b}$ presumed an influence of change in company management on pricing of the services. The hypothesis was not confirmed $(p>0.05)$. Hypothesis 1c, presuming an impact of management changes on staff size, was not confirmed $(p>0.01)$. Hypothesis 1d, presuming the impact of the company size on changes in company management, was not confirmed $(p>0.05)$. Hypothesis $1 e$, involving the influence of the company type on changes in company management, was not confirmed $(p>0.05$ ). Hypothesis $1 f$, presuming the influence of crisis perceptions on changes in company management, was confirmed in part $(p<0.05)$. The crisis was seen as a positive factor, not as a negative factor the way it was presumed. The impact of this factor indicates medium dependence $(V=0.442)$.

\section{Perceptions of the Economic Crisis as the External Influence Factor of Company Performance}

Generally, we can say, as shown in Figure 8, that the crisis is perceived rather positive in terms of changes in company management. This means that the crisis is seen as a source of new opportunities and potential for functional improvements in the company.

\section{Fig. 8: Perceptions of the economic crisis as the influence factor for company}

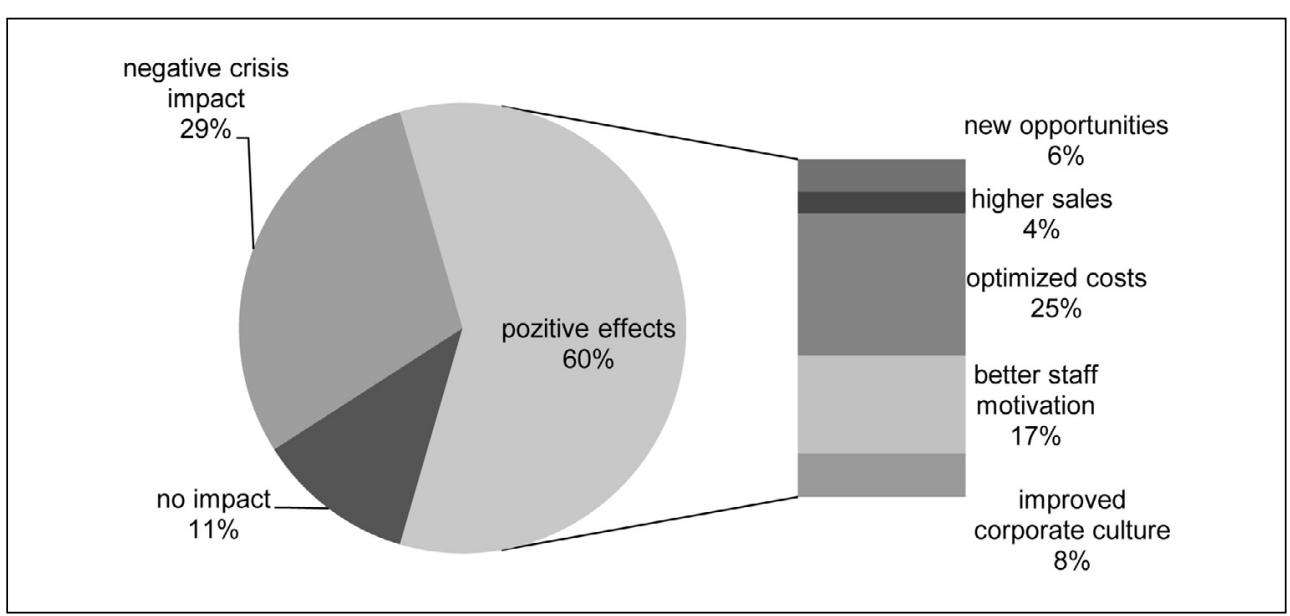

Source: custom data

The perception of the economic crisis as a factor influencing the situation of a company depends on the company type and is independent on the company size. It is perceived as a negative factor by businesses such as a lodging house, a camp-site, a bungalow site and a hostel. Hotels perceive the economic crisis rather as a positive factor that can bring new opportunities for the company.

To confirm hypotheses $\mathrm{H} 2 \mathrm{a}-\mathrm{H} 2 \mathrm{~b}$ established, an analysis of categorical data was performed, with its results shown in Table 4 below.

\begin{tabular}{l|c|c|c} 
Tab. 4: & \multicolumn{3}{c}{$\begin{array}{c}\text { Analysis results of categorical } \\
\text { data for Hypotheses H2a-H2f }\end{array}$} \\
\hline & $\begin{array}{c}\text { Pearson } \\
\text { coefficient }\end{array}$ & $\begin{array}{c}\text { Cramer } \\
\text { coefficient V }\end{array}$ & $\mathbf{p}$ \\
\hline size & 14.235 & 0.314 & 0.163 \\
\hline type & 67.391 & 0.433 & 0.017 \\
\hline \multicolumn{4}{c}{ Source: custom data }
\end{tabular}

Hypothesis 2a presumed an influence of the company size on perceptions of the economic crisis as an external factor 
influencing the company performance. This hypothesis was not confirmed $(p>0.05)$. Hypothesis $2 b$, presuming the influence of the company type on perceptions of the economic crisis, was confirmed $(p<0.05)$. The impact of this factor on the method choice indicates medium dependence $(\mathrm{V}=0.433)$.

\section{Generation and Use of Contingency Plan in Tourism Enterprises}

To confirm the set of hypotheses $\mathrm{H} 3 \mathrm{a}-\mathrm{H} 3 \mathrm{~b}$, an analysis of categorical data analysis was performed, with its results recorded in Table 5 below.

\begin{tabular}{l|c|c|c} 
Tab. 5: & \multicolumn{3}{c}{$\begin{array}{c}\text { Analysis results of categorical } \\
\text { data for Hypotheses H3a-H3b }\end{array}$} \\
& $\begin{array}{c}\text { Pearson } \\
\text { coefficient }\end{array}$ & $\begin{array}{c}\text { Cramer } \\
\text { coefficient V }\end{array}$ & $\mathbf{p}$ \\
\hline size & 81.624 & 0.753 & 0.000 \\
\hline type & 47.982 & 0.577 & 0.000 \\
\hline
\end{tabular}

Source: custom data

Hypothesis $3 a$ presumed an influence of the company size on the generation and the use of a contingency plan within the company. The hypothesis has been confirmed $(p<0.01)$. The impact of this factor indicates high dependence level $(V=0.753)$. Hypothesis $3 b$, presuming an influence of the company type on the generation and the use of the contingency plan, was confirmed. The impact of this factor on the method choice indicates medium dependence $(\mathrm{V}=0.577)$.

A summary of the hypotheses and analysis results is listed in table 6 .

\section{Discussion}

At present, a large number of economies around the world are struggling with the economic crisis, which brought about significant impact on quite a number of industries. The global crisis, affecting all levels of the global business environment, from the macro-environment down to the micro-environment of enterprises, is the most noticeable change affecting business management. As a result of the global economic crisis, the hospitality and tourism industry experienced a serious downturn in sales and profitability [9]. The current economic crisis has affected a large number of individuals, companies and countries [17].
The effects of the global economic crisis can be seen from different points of view. This research study focuses on the impact of the economic crisis on management of companies active in the tourism industry. Tourism industry is vulnerable to various crises and disasters, and its growth has been impeding due to unpleasant situations [6].

The research results presented above have led to certain interesting conclusions in terms of changes in the management of tourism companies. As obvious from previous results, a change in company management hardly involved pricing, service scope and file size.

The research study allowed finding out that most companies approached (55\%) do not use and generate a contingency plan. Microenterprises and small enterprises do not generate contingency plans, thus unable to use them either. Medium-sized enterprises typically create contingency plans, but fail to use them in the context of the economic crisis. Regarding the company type, the results looked identical. Businesses within the hotel category do write contingency plans, but fail to use them throughout the economic crisis. Businesses in the category of boarding houses, camp-sites, bungalow sites and hostels do not generate contingency plans and do not use them.

Apart from affecting the business environment in the Czech Republic, the current global crisis has a truly international, global impact. The changes are visible not only on the level of demand and supply in goods and services, but they reach deeper, up to the managerial practices within the companies.

Due to the nature of tourism, which is a non-essential product, the industry was severely hit but the crisis. Apart from the changes in customer preferences and needs that had to be addressed flexibly by managers, there was a need to change the managerial practice within companies operating in the tourism industry. Managers were pushed to take austerity measures, at the same time ensuring better satisfaction on part of customers. Despite the declining demand on part of clients, the scope of services on offer as well as their quality improved. As proved in the research study, nearly $40 \%$ of accommodation providers in the Olomouc region carried out changes within the management of the company during the crisis. 


\section{hypothesis}

H1a: Change in company management of the accommodation provider, as a result of the economic crisis, is manifested through a change of services on offer. There is a reduction in the supply of services.

$\mathrm{H} 1 \mathrm{~b}$ : Change in company management of the accommodation provider, as a result of the economic crisis, is manifested through a change in pricing for services on offer. Specifically, there is an increase in prices for services on offer.

$\mathrm{H} 1 \mathrm{c}$ : Change in company management of the accommodation provider, as a result of the economic crisis, is manifested through a change in the staff size.

The staff size is reduced.

$\mathrm{H} 1 \mathrm{~d}$ : A change in company management of the accommodation provider, as a result of the economic crisis, is influenced by the size of the company. Changes in the management practices are best visible in small and medium-sized enterprises.

$\mathrm{H} 1 \mathrm{e}$ : A change in company management of the accommodation provider, as a result of the economic crisis, is influenced by the size of the company. A change in management occurs mostly in companies such as boarding houses, camp-sites, bungalow sites and hostels. Hotels as a category are not influenced considerably by changes in management.

$\mathrm{H} 1 \mathrm{f}$ : A change in company management of the accommodation provider, as a result of the economic crisis, is influenced by the perception of the crisis and its impact on the company. A change in the company management occurs especially if the crisis is seen as a negative factor of the company development.

$\mathrm{H} 2 \mathrm{a}$ : Perceptions of the economic crisis, as a major external factor of the accommodation provider, depend on the company size. Small and medium-sized enterprises perceive the economic crisis as a threat to their commercial activities.

$\mathrm{H} 2 \mathrm{~b}$ : Perceptions of the economic crisis, as a major external factor of the accommodation provider, depend on the company type. Boarding houses, camp-sites, bungalow sites and hostels perceive the economic crisis as a threat to their commercial activities.

H3a: The generation and use of a crisis plan is influenced by the size of the accommodation provider. Contingency plans tend to be made rather by large companies.

$\mathrm{H} 3 \mathrm{~b}$ : The generation and use of a crisis plan is influenced by the type of the accommodation provider. Contingency plans tend to be made by hotels. result

confirmed

partially

not confirmed

not confirmed

not confirmed

not confirmed

confirmed partially

not confirmed

confirmed

confirmed

confirmed

\section{Conclusion}

As demonstrated by the research study, the change itself did not influence aspects such as staff downsizing and price rises for the services provided. No influence was proved to be linked to the size and type of the accommodation facility in terms of manager replacement. A significant change in management occurred in particular where the crisis was perceived in negative terms. In such cases, there was a partial, sometimes complete replacement of top managers, involving considerable changes in the management policies.

The crisis was perceived negatively even if the business people decided to ignore the crisis, either through a lack of activity in terms of manager replacement, or through their unwillingness to adjust to customers. A decline in the customer demand for the specific accommodation facility was noted then, and clients moved elsewhere, mostly to competitors. 


\section{Ekonomie}

By contrast, those operators who have taken advantage of the great changes in the market and began to adapt in a flexible way were able to welcome a sufficient number of satisfied customers to their facilities, and they assessed the crisis outcome in positive terms.

Whatever the reaction of managers was, the fact remains that the crisis brought about a purifying effect on companies. There has been a development of the enterprises prepared and able to take tourism a step further, thus enjoying a potential for future; at the same time, companies without this essential potential lost ground or were entirely dissolved.

This article is the outcome of the Student Grant Competition grant, project no. SGS 8/2012 Světová krize a její dopady na cestovní ruch v Olomouckém kraji - The World Crisis and Its Impact on Tourism in the Olomouc Region.

\section{References}

[1] ANTUŠÁK, E. Krizový management. Hrozby, krize, príležitosti. 1st ed. Praha: Wolters Kluwer ČR, 2009. 396 p. ISBN 978-80-7357-488-8.

[2] BUDÍKOVÁ, M., KRÁLOVÁ, M., MAROŠ, B. Průvodce základními statistickými metodami. Praha: Grada Publishing, 2010. 272 p. ISBN 97880-247-3243-5.

[3] ČESKÝ STATISTICKÝ ÚŘAD. Cestovní ruch [online]. Praha: Český statistický úřad, c2013. [cit. 2013-07-10]. Available from: http://www.czso.cz /csu/redakce.nsf/i/cestovni_ruch.

[4] ČTK. Cestovní ruch čeká vina propouštění, bude muset odejít sedm procent zaměstnanců. [online]. Economia, 2010 [cit. 2012-09-09]. Available from: http://byznys.ihned.cz/zpravodajstvicesko/c1-41501780-cestovni-ruch-ceka-vlnapropousteni-bude-muset-odejit-sedm-procentzamestnancu.

[5] DORŇÁK, O. Světová finanční krize: Co stálo na počátku? [online]. Praha: Fincentrum, 2009-02-13 [cit. 2013-03-17]. Available from: http://www. investujeme.cz/svetova-financni-krize-co-stalona-pocatku/.

[6] GHADERI, Z., SOM, A.P.M. Impacts of Global Economic Crisis on Tourism Business in Penang. South Asian Journal of Tourism and Heritage. 2012, Vol. 5, No. 1, pp. 40-46. ISSN 0974-5432.

[7] HENDL, J. Přehled statistických metod zpracování dat: analýza a metaanalýza dat. Praha:
Portál, 2006. p. 305-343. ISBN 80-7367-123-9. [8] HORNUNGOVÁ, J. Vliv „Velké deprese“ na činnost menších - rodinných firem. In LOKAJ, A. a HLAVÁČEK, K. (Eds.). "Velká deprese" a její odraz $v$ ekonomické teorii a praxi. [CD-ROM]. 1. vyd. Ostrava, VŠB - Technická univerzita Ostrava, 2009. ISBN 978-80-248-2150-4.

[9] HOSPODÁŘSKÁ KOMORA ČR. Hotely ztratily počátkem roku meziročně 8,4 procenta hostů. [online]. 2009. [cit. 2012-09-03]. Available from: http://www.komora.cz/regionalni-a-oboroveinformace/oborove-informace-1/obchod-acestovni-ruch-1/informace-z-oboru-obchod-acestovni-ruch/hotely-ztratily-pocatkem-roku-mezir ocne-8-4-procenta-hostu.aspx.

[10] KAPIKI, S.T. The Impact of Economic Crisis on Tourism and Hospitality: Results from a Study in Greece. Central European Review of Economics and Finance. 2012, Vol. 2, No. 1, pp. 19-30. ISSN 2082-8500.

[11] LUNGOVÁ, M. Hospodářská krize 2008-2009: Analýza přícin. E+M Ekonomie a Management. 2011, Vol. 14, Iss. 2, pp. 22-30. ISSN 1212-3609. [12] MIKOLAJ, J. a kol. Krízový manažment ako spoločensko-vedný problém. 1st ed. Žilina: Žilinská univerzita v Žilině, 2000. 141 p. ISBN 80-88829-54-2.

[13] PENDERY, D. Three Top Economists Agree 2009 Worst Financial Crisis Since Great Depression; Risk Increase if Right Steps are Not Taken [online]. Reuters, 2009-02-27 [cit. 2012-05-28]. Available from: http://www.reuters.com/article/ 2009/02/27/idUS193520+27-Feb-2009+BW20090227.

[14] ŠıMÁK, L. Krízový manažment vo verejnej správe. 2nd ed. Žilina: Žilinská univerzita v Žilině, 2001. 245 p. ISBN 80-88829-12-5.

[15] ŠPAČEK, M. Řízení podniku v globálním podnikatelském prostředí - staré koncepty s novým obsahem. Ekonomika a management [online]. 2008, Iss. 3 [cit. 2013-03-17], 11 p. Available from: http://www.ekonomikaamanagement. cz/cz/clanek-rizeni-podniku-v-globalnimpodnikatelskem-prostredi-stare-koncepty-snovym-obsahem.html. ISSN 1802-8934.

[16] UNIHOST. Hospodářská krize v ČR [online]. Ostrava: UNIHOST, 2009-05-25 [cit. 2012-09-02]. Available from: http://www.unihostostrava.cz/ www/cz/aktuality/hospodarska-krize-vcr/\#article_8728.

[17] VAŠTÍKOVÁ, M. Global Economic Crisis and Marketing Defence of the Tertiary Sector. Acta Academica Karviniensia. 2012, Iss. 4, pp. 163-172. ISSN 1212-415X. 
[18] ZAPLETALOVÁ, Š. Strategický management $v$ době světové krize. In Sborník recenzovaných príspěvků z 1. mezinárodní vědecké conference Ekonomika a ř́zení podniku ve 21. století. 1st ed. Ostrava: VŠB, 2012. ISBN 978-80-248-2768-1. [19] ZUZÁK, R., KÖNIGOVÁ, M. Krizové ř́zení podniku. 2nd ed. Praha: Grada Publishing, 2009. 256 p. ISBN 978-80-247-3156-8.
Ing. Barbora Antonová

Silesian University in Opava

School of Business Administration in Karviná

Department of Management and Business antonova@opf.slu.cz

Ing. Šárka Zapletalová, Ph.D.

Silesian University in Opava

School of Business Administration in Karviná

Department of Management and Business

zapletalova@opf.slu.cz 


\section{Abstract}

\section{THE ECONOMIC CRISIS AND COMPANY MANAGEMENT: INFLUENCES AND CONSEQUENCES}

\section{Barbora Antonová, Šárka Zapletalová}

The tourism industry has been considerably affected by the global economic crisis over the most recent years, with its roots identified in the US mortgage market segment. This crisis has caused fluctuations in the markets across all industries, triggering uncertainty in nearly every businessperson in the Czech Republic.

By their nature, tourist services are non-essential products, used by customers to satisfy their needs only. Thus, in those times of uncertainty, customers tend to cut down on these services to a certain minimum level. This fact manifested itself during the crisis in 2007-2012.

The article presents the impact of the global crisis on the tourism industry, in particular, on accommodation providers in the Olomouc region. The aim of the article was to explore the impact of this crisis on management of group accommodation facilities. The introductory chapter discusses the theoretical aspect of the economic crisis and its relations with company management, as well as the impact of the crisis on provision of accommodation services in the reference period across the nation. Following this, hypotheses are established, to be subsequently assessed by means of the primary research run as the questionnaire poll in the Olomouc region. The article focuses essentially on a change of managers in accommodation facilities, other measures taken by managers during the crisis, and the consequences of these measures.

Key Words: Management, crisis management, tourism, world crisis, accommodation facilities.

JEL Classification: F18, F14, M10.

DOI: 10.15240/tul/001/2014-1-001 